http://dx.doi.org/10.18778/1643-0700.20.10

\author{
Lukasz ANTOSIK*, Błażej MUZOLF**
}

\title{
ROSYJSKA IKONA PODRÓŻNA ODKRYTA NA CMENTARZU PRZYKOŚCIELNYM W LUTOMIERSKU
}

\begin{abstract}
Streszczenie. W 2018 roku przy kościele parafialnym pw. Wniebowzięcia NMP w Lutomiersku prowadzone były sondażowe badania archeologiczne. W ich wyniku w jednym z grobów natrafiono na brązową lub mosiężną ikonkę podróżną powstałą w wytwórni w Guślicach (Rosja) w XIX lub na początku XX w. Lutomierski egzemplarz ikony jest tryptykiem, składającym się na podobieństwo ołtarza. We wnętrzu umieszczona jest postać Matki Boskiej Iwerskiej, której pierwowzór związany jest z monastyrem Iwiron na Górze Athos w Grecji. Przedmiot dodatkowo znajdował się w woreczku jedwabnym. Znalezisko to poświadcza, że na lutomierskim cmentarzu przykościelnym być może chowano także wyznawców prawosławia.
\end{abstract}

Słowa kluczowe: ikona podróżna, szkaplerz, jedwab, Lutomiersk, badania archeologiczne

W związku z przystąpieniem w 2018 r. do prac mających na celu budowę parkingu przy kościele parafialnym pw. Wniebowzięcia Najświętszej Maryi Panny w Lutomiersku konieczne było przeprowadzenie ograniczonych przestrzennie prac archeologicznych. Podjęte działania związane były z ochroną konserwatorską jaką objęty jest cały obszar miejscowości Lutomiersk, co skutkuje tym, że wszelkie prace ziemne na jej obszarze muszą być prowadzone pod nadzorem archeologa lub też poddane badaniom. Teren inwestycji przylegał bezpośrednio do drugiego najstarszego kościoła w Lutomiersku, w związku z czym należało się w tym miejscu spodziewać cmentarza przykościelnego ${ }^{1}$.

* Łukasz Antosik, mgr, Instytut Archeologii i Etnologii Polskiej Akademii Nauk Ośrodek Badań nad Dawnymi Technologiami, 90-364 Łódź, ul. Tylna 1, e-mail: 1.antos@wp.pl.

** Błażej Muzolf, mgr, Zespół Badań Konserwatorskich Lutomiersk, e-mail: blazejmuzolf@ wp.pl.

1 Badaniami archeologicznymi kierował mgr Błażej Muzolf. 
Lutomiersk jest jedną z najstarszych i najwcześniej odnotowanych miejscowości na obszarze Polski Środkowej. Do rangi miasta został podniesiony już w 1274 roku przez księcia Leszka Czarnego. W 1311 roku Władysław Łokietek nadał Lutomiersk rycerskiemu rodowi Zarembów. Najpewniej już pod koniec XIV w. połowa miasta, decyzją króla Władysława Jagiełły trafiła w ręce wywodzącego się z Ziemi Dobrzyńskiej Jana z Chełmicy, herbu Jastrzębiec, którego potomkowie z czasem przyjęli nazwisko Lutomierskich. Nadanie to zostało potwierdzone dokumentem królewskim z 1406 r. ${ }^{2}$

To właśnie z tą rodziną powiązany jest teren na którym prowadzona była wzmiankowana przykościelna inwestycja. Pierwsza informacja o kościele pochodzi z wystawionego w 1448 r. dokumentu, w którym wymieniono „nowy kościół” należący do Mikołaja Lutomierskiego ${ }^{3}$. Był to obiekt drewniany, będący filią, starszej parafialnej świątyni pw. św. Bartłomieja w Lutomiersku, obecnie nie istniejący, który zlokalizowano na „wzgórzu” przy obecnym Placu Bartłomieja w Lutomiersku4.

W miejscu „nowego kościoła” wzniesionego przez Lutomierskich, wybudowano w latach 1781-1783, staraniem Barbary z Duninów księżnej Sanguszkowej murowaną świątynię pw. Wniebowzięcia NMP, będącą obecnie siedzibą parafii po zniszczeniu kościoła św. Bartłomieja ${ }^{5}$.

Zgodnie z przewidywaniami w zrealizowanych wykopach sondażowych odkryto pochówki, które wystąpiły w co najmniej dwóch lub trzech warstwach. W odsłoniętych grobach zidentyfikowano zarówno osoby dorosłe jak i dzieci. Zmarli byli chowani w zarówno w całunach, jak i trumnach, o czym mogą świadczyć odkryte żelazne gwoździe do ich zbijania.

$\mathrm{O}$ znaleziskach odnotowanych w dwóch grobach należy wspomnieć szerzej. W pierwszym z nich odkryto niewielką miedzianą monetę w postaci denara jagiellońskiego z XV w. Numizmat niewątpliwie poświadcza, iż pierwsze składane pochówki zmarłych w tym miejscu przypadają już na wiek XV, czyli na czasy wzniesienia.

Drugim interesującym zabytkiem jest odkryta w grobie dorosłej osoby, tzw. ikona podróżna wykonana z brązu, którą zarejestrowano w partii piersiowej szkieletu. Dodatkowo przy przedmiocie zachowały się pozostałości organiczne.

Wydobyta ikona składa się z trzech zamykających się części na podobieństwo ołtarza, czyli tryptyku. Ikony takie zabierali ze sobą w podróż wyznawcy prawosławia i stanowić miały namiastkę ołtarza w miejscach gdzie nie istniały cerkwie. Najczęściej wytwarzane były z metalu, ale także z surowców organicznych

2 A. Szymczakowa, Szlachta sieradzka w XV wieku, Wydawnictwo Uniwersytetu Łódzkiego, Łódź 1998, s. 226.

3 A. Szymczakowa, Włość Lutomierskich u schyłku średniowiecza, „Rocznik Łódzki” 2005, t. LII, s. 151.

4 Z. Głąb, Socjotopografia Lutomierska (XIII-XVIII w.), Księży Młyn Dom Wydawniczy, Łódź 2017, s. 297.

A. Szymczakowa, Włość Lutomierskich ..., s. 154. 
np. drewna. Odkryty obiekt to najpewniej odlew z brązu (brak obecnie analizy metalograficznej) o wymiarach 5,4 x 5,2 cm w zamknięciu oraz 5,4 x 9,5 cm po rozłożeniu. Jednoznacznie można określić pochodzenie zabytku, który został wykonany w Rosji, zapewne w wytwórni w Guślicach w XIX w. lub w początkach $\mathrm{XX}$ wieku. Miejscowość ta należała do jednych z bardziej znanych ośrodków odlewniczych w drugiej poł. XVIII i w XIX wieku'

Pewną analogią jest odkrycie jednoczęściowej ikony podróżnej przy szczątkach żołnierza zapewne z armii carskiej, poległego w 1914 r., w trakcie badań archeologicznych na zamku Pilcza w Smoleniu (fot. 3) (badania własne B. Muzolfa - 2014 r.).

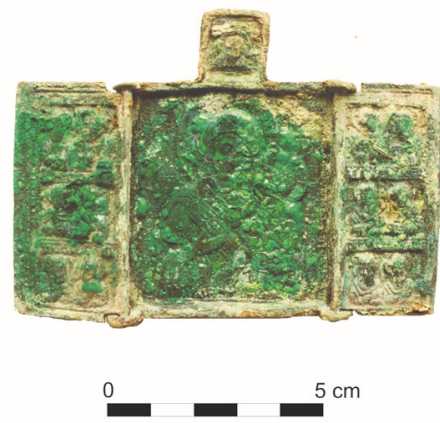

Fot. 1. Ikonka przed konserwacją Źródło: P. Muzolf, 2018 r.

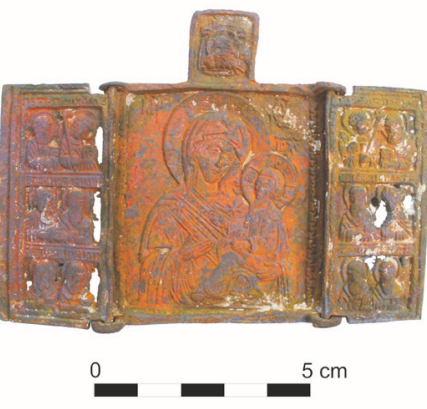

Fot. 2. Ikonka po konserwacji

Źródło: P. Muzolf, 2018 r.

W centralnej partii otwartej ikony została umieszczona postać Matki Boskiej Iwerskiej. Pierwowzór tego wizerunku wywodzi się z monastyru Iwiron (stąd nazwa) na Górze Athos w Grecji i jest datowany, na co najmniej IX w. Jest to

6 P. Sawicki, Rosyjska ikona metalowa w kolekcji Muzeum Ikon w Supraślu. Katalog zbiorów Piotr Sawicki, Wydawnictwo Muzeum Podlaskie w Białymstoku, Białystok 2014, s. 18. 
przedstawienie Matki Boskiej najbardziej czczone w kościele prawosławnym. Na skrzydłach tryptyku umieszczone zostały wizerunki dwunastu świętych oraz archaniołów, w parach, po sześciu na każdym ze skrzydeł (fot. 1 i 2).

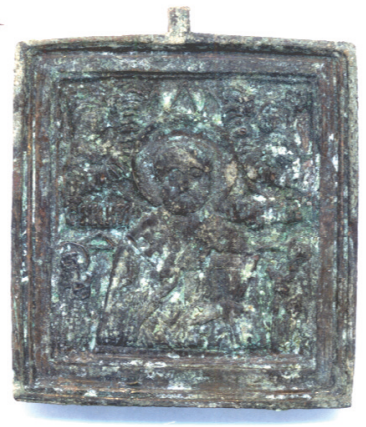

Fot. 3. Ikonka podróżna odkryta na zamku Pilcza w Smoleniu Źródło: P. Muzolf, 2014 r.

Jak wcześniej wspomniano przy tryptyku zachowały się pozostałości pochodzenia organicznego. Dokładne oględziny pozwoliły wydzielić fragment tkaniny mocno przywartej do ikony oraz resztki roślinne (słomę).

W celu uzyskania dokładniejszych informacji dotyczących surowca i parametrów technologicznych tkaniny przeprowadzono analizę mikroskopową ${ }^{7}$ która miała umożliwić określenie kilku parametrów, takich jak: splot tkacki, ewentualne błędy tkackie, surowiec, gęstość tkaniny, grubość i skręt przędzy.

Badania wykazały, że mamy do czynienia $\mathrm{z}$ fragmentem wyrobu jedwabnego wykonanego $\mathrm{w}$ splocie płóciennym. Użyty przeplot należy do najprostszego i jednocześnie najstarszego splotu tkackiego stosowanego po dzień dzisiejszy ${ }^{8}$. Charakteryzuje się on pokryciem nici osnowy i wątku w układzie szachownicowym, gdzie jedna nić osnowy przypada na jedną nić wątku (ryc. 1). Poczynione analizy zabytku odnalezionego w Lutomiersku nie wykazały skrętu użytych włókien, co jest dość częste w przypadku nitek jedwabnych. Obliczona średnia gęstość wyrobu w osnowie wynosi 30 nitek na $1 \mathrm{~cm}$, z kolei w wątku 22-23 nitki na $1 \mathrm{~cm}$. Średnia grubość użytej przędzy w obu systemach wynosi około $0,23 \mathrm{~mm}$. Zaznaczyć trzeba, że użycie splotu płóciennego zapewne niosło za sobą zmniejszenie kosztów produkcji materiału, poprzez redukcję potrzebnego czasu na jego utkanie i pozwalało na zużycie mniejszej ilości

\footnotetext{
7 Badania przeprowadzono w Instytucie Archeologii i Etnologii PAN Ośrodek Badań nad Dawnymi Technologiami w Łodzi.

\& T.J. Chmielewski, Po nitce do ktębka... O przędzalnictwie i tkactwie młodszej epoki kamienia w Europie środkowej, Wydawnictwo Naukowe Semper, Warszawa 2009, s. 270-278.

9 M. Michałowska, Leksykon włókiennictwa, Krajowy Ośrodek Dokumentacji Zabytków, Warszawa 2006, s. 340.
} 
surowca niż przy tkaninach o splotach wzorzystych. W ostatecznym rozrachunku otrzymywano materiał ze szlachetnego włókna, ale dostępny dla szerszego grona odbiorców.

Jak już wielokrotnie było podkreślane w literaturze tematu, prosty i jednocześnie powszechnie stosowany system przeplotu powoduje, że niemożliwe jest stwierdzenie miejsca i czasu produkcji takich wyrobów ${ }^{10}$. Tkaniny jedwabne o analogicznych parametrach są powszechnie odkrywane na późnośredniowiecznych i nowożytnych stanowiskach archeologicznych na terenie całej Polski ${ }^{11}$. Pozyskany w trakcie badań wykopaliskowych fragment tekstylny przylegający do ikony należy do wyrobów prostych i można go uznać za resztki opakowania/ woreczka, w którym umieszczono szkaplerz.
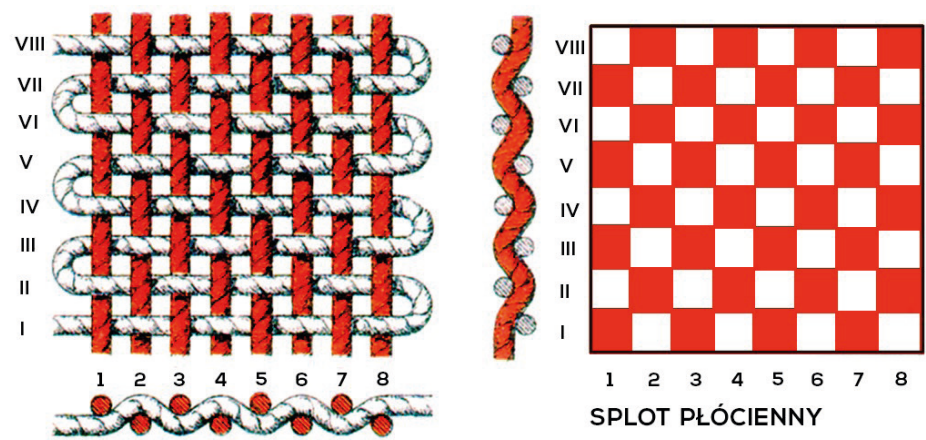

Ryc. 1. Schemat splotu płóciennego

Źródło: P. Kenig, W. Stysińska 2008, s. 78

Pomimo ograniczonego obszaru badania archeologiczne ujawniły kolejny element dokumentujący bogatą historię Lutomierska, w przeszłości znacznego ośrodka osadniczego w tej części kraju, który to ukazem carskim w 1870 r. utracił prawa miejskie. Jednoznaczna identyfikacja znaleziska wskazuje, że na lutomierskim cmentarzu przykościelnym chowano także wyznawców prawosławia, być może w wyznaczonej osobnej kwaterze.

Co także warte podkreślenia odkryty fragment tekstylny jest kolejnym zabytkiem tego typu pozyskanym $\mathrm{w}$ trakcie badań archeologicznych prowadzo-

10 J. Maik, Sploty jedwabnych tkanin wykopaliskowych znalezionych w Polsce, [w:] M. Głosek (red.), Archeologia i starożytnicy. Studia dedykowane Profesorowi Andrzejowi Abramowiczowi w 70 rocznicę urodzin, Instytut Archeologii i Etnologii Polskiej Akademii, Łódź 1997, s. 174.

11 J. Jabłońska, Tkaniny z badań archeologicznych na wyspie spichrzów w Gdańsku w latach 2004-2006, [w:] H. Paner, M. Fudziński, Z. Borcowski (red.), Stan badań archeologicznych miast w Polsce, Muzeum Archeologiczne w Gdańsku, Gdańsk 2009, s. 210; J. Maik, Wstępne wyniki badań średniowiecznych i nowożytnych tekstyliów z wykopalisk w Elblagu, „Archeologia Elbingensis" 1997, t. 2, s. 160. 
nych na terenie Lutomierska. Dotychczas wyroby włókiennicze znaleziono także na cmentarzysku wczesnośredniowiecznym ${ }^{12}$, przy kościele św. Bartłomieja ${ }^{13}$ oraz na stanowisku Lutomiersk-Koziówka 3a-c ${ }^{14}$.

\section{Bibliografia}

Antosik Ł., Muzolf B., Analiza technologiczna nowożytnych fragmentów tekstylnych z Lutomierska, pow. Pabianice województwo łódzkie, „Prace i Materiały Muzeum Archeologicznego i Etnograficznego w Lodzi. Seria Archeologiczna” 2010-2012, nr 45, s. 427-435.

Chmielewski T.J., Po nitce do ktębka... O przędzalnictwie i tkactwie młodszej epoki kamienia w Europie środkowej, Wydawnictwo Naukowe Semper, Warszawa 2009.

Głąb Z., Socjotopografia Lutomierska (XIII-XVIII w.), Księży Młyn Dom Wydawniczy, Łódź 2017.

Grupa M., Rybka K., Wyniki prac konserwatorskich przy mieczu ze stanowiska Lutomiersk-Koziówki 3a-c, [w:] R. Grygiel (red.) Lutomiersk-Koziówki, stanowisko 3a-c, pow. pabianicki, woj. łódzkie. Wielokulturowy zespót osadniczy od schyłkowego paleolitu po okres nowożytny, ,Biblioteka Muzeum Archeologicznego i Etnograficznego w Łodzi” 2012, nr 39, Muzeum Archeologiczne i Etnograficzne w Łodzi.

Jabłońska J., Tkaniny z badań archeologicznych na wyspie spichrzów w Gdańsku w latach 2004-2006, [w:] H. Paner, M. Fudziński, Z. Borcowski (red.), Stan badań archeologicznych miast w Polsce, Muzeum Archeologiczne w Gdańsku, Gdańsk 2009, s. 201-214.

Kenig P., Stysińska W., Muzeum Techniki i Włókiennictwa w Bielsku-Białej. Zarys dziejów bielskiego przemystu i przewodnik po ekspozycji włókienniczej, Muzeum w Bielsku-Białej, Bielsko-Biała 2008.

Maik J., Sploty jedwabnych tkanin wykopaliskowych znalezionych w Polsce, [w:] M. Głosek (red.), Archeologia i starożytnicy. Studia dedykowane Profesorowi Andrzejowi Abramowiczowi w 70 rocznice urodzin, Instytut Archeologii i Etnologii Polskiej Akademii Nauk, Łódź 1997, s. 173-184.

12 A. Nahlik, Wyniki analizy tkanin, [w:] A. Nadolski, A. Abramowicz, T. Poklewski (red.), Cmentarzysko z XI wieku w Lutomiersku pod Łodzia, ,Acta Archaeologica Uniwersitatis Lodziensis" 1959, nr 7, s. 140-141.

13 Ł. Antosik, B. Muzolf, Analiza technologiczna nowożytnych fragmentów tekstylnych z Lutomierska, pow. Pabianice województwo łódzkie, „Prace i Materiały Muzeum Archeologicznego i Etnograficznego w Łodzi. Seria Archeologiczna" 2010-2012, nr 45, s. 427-435.

14 M. Grupa, K. Rybka, Wyniki prac konserwatorskich przy mieczu ze stanowiska LutomierskKoziowki 3a-c, [w:] R. Grygiel (red.), Lutomiersk-Koziówki, stanowisko 3a-c, pow. pabianicki, woj. łódzkie. Wielokulturowy zespół osadniczy od schyłkowego paleolitu po okres nowożytny, „Biblioteka Muzeum Archeologicznego i Etnograficznego w Łodzi” 2012, nr 39, Muzeum Archeologiczne i Etnograficzne w Łodzi. 
Maik, J., Wstępne wyniki badań średniowiecznych i nowożytnych tekstyliów z wykopalisk w Elblagu, „Archeologia Elbingensis” 1997, t. 2, s. 155-170.

Michałowska M., Leksykon włókiennictwa, Krajowy Ośrodek Dokumentacji Zabytków, Warszawa 2006.

Nahlik A., Wyniki analizy tkanin, [w:] A. Nadolski, A. Abramowicz, T. Poklewski (red.), Cmentarzysko z XI wieku w Lutomiersku pod Łodzia, „Acta Archaeologica Uniwersitatis Lodziensis" 1959, nr 7, s. 140-141.

Sawicki P., Rosyjska ikona metalowa w kolekcji Muzeum Ikon w Supraślu. Katalog zbiorów Piotr Sawicki, Wydawnictwo Muzeum Podlaskie w Białymstoku, Białystok 2014.

Szymczakowa A., Szlachta sieradzka w XV wieku, Wydawnictwo Uniwersytetu Łódzkiego, Łódź 1998.

Szymczakowa A., Włość Lutomierskich u schyłku średniowiecza, „Rocznik Łódzki” 2005 , t. LII, s. 151-176.

[Artykuł wpłynął: lipiec 2019; akceptacja: czerwiec 2020]

\title{
A RUSSIAN ICON FOUND \\ AT CHURCH CEMETERY IN LUTOMIERSK
}

\begin{abstract}
Summary
During archaeological works carried out at the cemetery of the parish church dedicated to the Blessed Virgin Mary in Lutomiersk, a bronze or brass traveller's icon was found in one of the graves. It was made in Guślice (Russia) in the $19^{\text {th }}$ or early $20^{\text {th }}$ century. The icon has the form of triptych, folding like an altar. Inside is the figure of the Holy Virgin, whose prototype is connected with the Iwiron monastery on Mount Athos in Greece. The icon was inside a silk pouch. This find indicates that members of the Orthodox Church were buried at Lutomiersk church cemetery.
\end{abstract}

Keywords: traveller's icon, scapular, silk, Lutomiersk, archaeological works 